\title{
Impella LD microaxial pump supporting combined mitral and coronary surgery in a patient with dilated cardiomyopathy. A short bridge to recovery?
}

\author{
Bartłomiej Szafron ${ }^{1}$, Radosław Hugon Smoczyński ${ }^{1}$, Dominik Drobiński ${ }^{1}$, Agnieszka Pawlak ${ }^{2}$, \\ Dariusz Wojciechowski ${ }^{3,4}$, Irena Maria Liszka ${ }^{1}$, Anna Witkowska ${ }^{1}, Z^{2 y g m u n t ~ K a l i c i n ́ s k i ~}{ }^{1}$, Robert Gil ${ }^{2}$, \\ Piotr Suwalski ${ }^{1,5}$
}

\author{
${ }^{1}$ Department of Cardiac Surgery, Central Teaching Hospital of the Ministry of Interior, Warsaw, Poland \\ ${ }^{2}$ Department of Interventional Cardiology, Central Teaching Hospital of the Ministry of Interior, Warsaw, Poland \\ ${ }^{3}$ Wolski Hospital, Warsaw, Poland \\ ${ }^{4}$ Institute of Biocybernetics and Biomedical Engineering PAS, Warsaw, Poland \\ ${ }^{5}$ Kazimierz Pulaski University of Technology and Humanities, Radom, Poland
}

Kardiochirurgia i Torakochirurgia Polska 2015; 12 (1): 56-59

\begin{abstract}
Cardiac surgeons have to face the problem of impaired left ventricle function in patients undergoing routine valve or coronary procedures. The intra-aortic balloon pump is not always effective in preventing cardiac failure. The idea of using a microaxial rotating pump as a short-term perioperative support seems to be a convenient solution. The case of a patient with dilated cardiomyopathy undergoing combined mitral and coronary surgery with elective use of the Impella LD pump is presented. Various options of applying the Impella device are discussed, especially as a bridge to transplant or bridge to recovery.
\end{abstract}

Key words: cardiac surgery, cardiac failure, VAD.

\section{Introduction}

Nowadays cardiac surgeons must face the problem of severely impaired left ventricle function almost on a daily basis. Heart transplantation, due to the limited donor pool, can be offered only to a small number of patients suffering from cardiac failure [1, 2]. Furthermore, the idea of long-term mechanical support as a destination therapy is still evolving [2]. Hence, efforts to optimize the results of routine cardiac surgery have to be undertaken. In a properly selected group of patients coronary surgery alone or combined with mitral surgery can improve both quality of life and long-term survival. Such surgery by definition is high risk. Cardioplegic arrest can contribute to further myocardial damage. With borderline ventricular function prior to surgery this may result

\section{Streszczenie}

$U$ chorych poddanych rutynowemu zabiegowi zastawkowemu lub wieńcowemu kardiochirurdzy niejednokrotnie muszą mierzyć się z problemem upośledzonej funkcji lewej komory. Kontrpulsacja wewnątrzaortalna nie zawsze jest w stanie zapobiec niewydolności serca. Użycie małej pompy wirnikowej jako krótkotrwałego wsparcia okołooperacyjnego wydaje się dobrym rozwiązaniem $\mathrm{w}$ takiej sytuacji. W pracy przedstawiono przypadek chorej z kardiomiopatią rozstrzeniową, u której podczas operacji plastyki zastawki mitralnej i pomostowania naczyń wieńcowych planowo użyto pompy Impella LD. Omówiono różne opcje zastosowania urządzenia Impella, szczególnie jako „pomostu” do przeszczepu lub do wyzdrowienia. Słowa kluczowe: chirurgia serca, niewydolność serca, VAD.

in failed weaning from cardiopulmonary bypass. In isolated coronary surgery beating heart strategy, either on or off pump seems to be a safer option. Its use however is hardly possible when mitral valve repair or replacement needs to be done. Intra-aortic balloon pump (IABP) is a gold standard here, but some patients may require more sophisticated mechanical assistance $[3,4]$. The idea of short-term, perioperative mechanical support, preferably with a low anticoagulation regime, looks very convenient in this respect [5]. Impella microaxial pumps (Abiomed Europe $\mathrm{GmbH}$, Aachen, Germany) seem to meet these criteria. They use the idea of pulling the blood from the left ventricle into the aorta, which is accomplished by means of a rotating impeller positioned in the aorta with the tip of the device and inlet area positioned in the left ventricle. This results in reduction of both

Address for correspondence: Bartłomiej Szafron, MD, PhD, Department of Cardiac Surgery, Central Teaching Hospital of the Ministry of Interior, 137 Wołoska St., 02-507 Warsaw, Poland, phone: +48 602379 843, e-mail: bszafron@mp.pl 
left ventricle end diastolic volume (LVEDV) and left ventricle end diastolic pressure (LVEDP). The systemic pressure and flow are increased. The less stretched left ventricle, with better subendocardial perfusion, has more time to recover. On the other hand, adequate systemic perfusion is maintained. Even a few hours of such support can change the odds. The Impella pump can be applied either by cardiologists (Impella 2.5/Impella CP) in a cath lab setting or by cardiac surgeons (Impella 5.0/Impella LD) in an operating theatre with either peripheral vascular or central direct access. Offering flow up to $5 \mathrm{l} / \mathrm{min}$, these devices have the potential to increase patients' chances significantly. The implantation techniques do not require any additional skills from either cardiologists or surgeons. The anticoagulation management requires only heparin infusion to keep activated clotting time (ACT) not shorter than $160 \mathrm{~s}$. Thanks to the automated controller with an intuitive, user friendly interface, operating the device can be easily mastered by doctors and nursing staff.

\section{Case presentation}

A 64-year-old woman suffering from ischemic dilated cardiomyopathy associated with mitral insufficiency was referred for combined treatment consisting of resynchronisation therapy followed by simultaneous coronary and mitral surgery. Initial echocardiography revealed impaired global contractility (ejection fraction [EF] 10-15\%), dilated left ventricle (left ventricle end diastolic diameter [LVEDD] $7.8 \mathrm{~cm}$ ), significant ventricular asynchrony $(50 \mathrm{~ms})$ and moderate mitral regurgitation (vena contracta [VC] $6 \mathrm{~mm}$ ) due to both restriction of the posterior leaflet and dilation of the mitral annulus $(5.5 \mathrm{~cm})$. There were no significant abnormalities regarding the right ventricle, pulmonary valve and tricuspid valve. Clinically the patient presented with end stage cardiac failure including resting dyspnea (NYHA IV). The patient underwent uneventful implantation of an ICD CRD (Maximo II), which resulted in improved exercise tolerance. This was consistent with post-procedure echocardiography showing no significant ventricular asynchrony (4 ms), slightly improved contractility (EF 20\%) and unchanged moderate mitral regurgitation ( $\mathrm{VC} 6 \mathrm{~mm}$ ). Therefore the

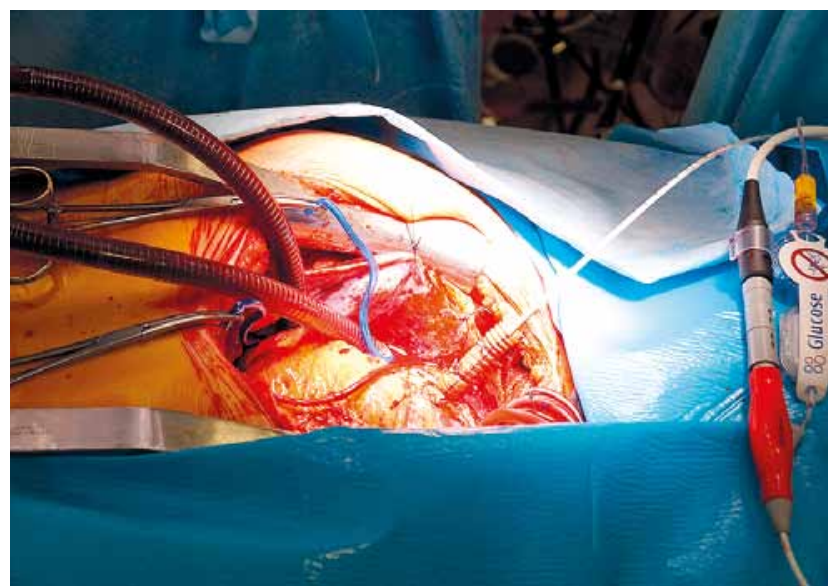

Fig. 1. Impella device inserted through the tubing graft anastomosed to the ascending aorta patient was referred for combined cardiac surgery including mitral repair and coronary grafting. Because of poor LV function and the complexity of the procedure, it was decided to apply short-term mechanical support during and after surgery. The Impella LD microaxial pump was chosen due to the simplicity of implantation and the low anticoagulation regime. Also, the Impella LD does not require a hybrid theater with fluoroscopic guidance. Routine surgery was performed. The surgical approach was achieved via median sternotomy. Cardiopulmonary bypass was established by means of selective bicaval cannulation. Antegrade cold blood cardioplegic solution was administered through the aortic root. The posterior descending artery (PDA) and left anterior descending artery (LAD) were grafted with the long saphenous vein and left internal thoracic artery respectively. The left atrium was entered in a routine manner after dissecting Sondergaard's plane. On inspection the echocardiographic findings were confirmed. The valve was repaired with a Physio $26 \mathrm{~mm}$ ring. The only surgical issue was severe atherosclerosis of the ascending aorta affecting both anastomosis of the vein graft and implantation of the Impella device. Before the implantation the device was prepared as per protocol. The purge system with $20 \%$ dextrose was installed. The device was primed, deaired and checked. Before insertion a $10 \mathrm{~mm}$ Dacron graft was anastomosed to the ascending aorta using a side biting clamp (Fig. 1). The Impella catheter was inserted through the graft and then, under transesophageal echocardiographic (TEE) guidance, was forwarded through the ascending aorta and the aortic valve into the left ventricle (Figs. 2 and 3). Immediately after confirming the position the impeller rotation was initialized. The target flow was achieved gradually within a few minutes. Weaning from cardiopulmonary bypass was accomplished on minimal inotropic support. The echo scan showed significant offloading of the left ventricle (Fig. 4). Meticulous attention was paid to maintain proper left ventricle volume preloading in order to avoid pump malfunction. After securing hemostasis the chest was closed, letting the driveline out above the suprasternal notch and through the upper end of the sternotomy wound. The pa-

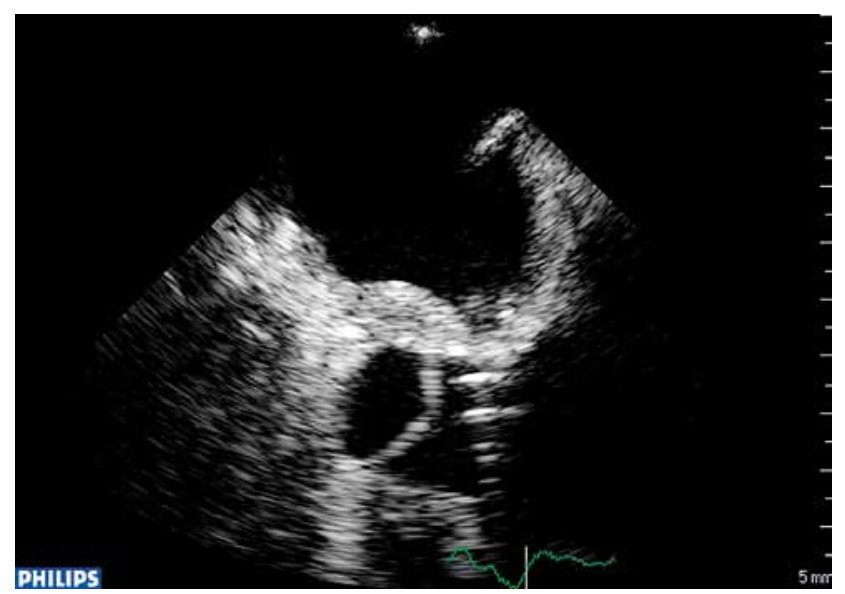

Fig. 2. Impella device in the ascending aorta, approaching the aortic valve 


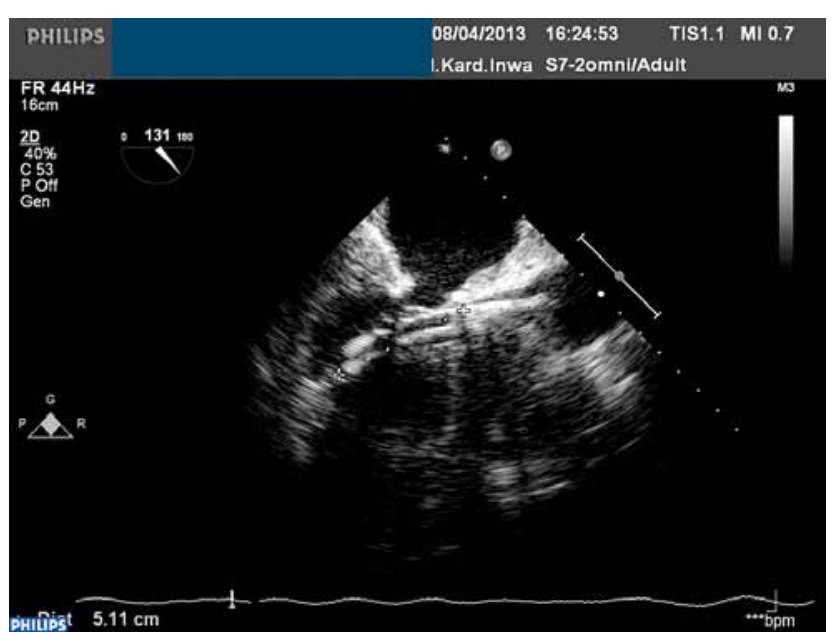

Fig. 3. Impella device finally positioned in the left ventricle

tient was transferred to intensive treatment unit (ITU) in a stable condition. There she was kept sedated and ventilated electively. Therapeutic activated clotting time (ACT) (160 s) was achieved by continuous heparin infusion. The position of the pump was checked daily and in case of any suspicion of malfunction. Adequate flow was maintained most of the time, with one episode of stopping of the machine, which was easily managed with fluid infusion. The inotropic support was reduced gradually without affecting hemodynamic stability. On the $2^{\text {nd }}$ postoperative day the device was explanted electively in the operating theatre. The further postoperative course was mainly uneventful, although prolonged mechanical ventilation was required (8 days). Episodes of AF were managed pharmacologically. Consecutive echo scans confirmed mild mitral regurgitation and poor LV function as before surgery. The patient was discharged home 20 days after surgery without signs of cardiac failure. The first follow-up visit two months after discharge confirmed good exercise tolerance and satisfactory echocardiographic findings (trace mitral regurgitation, LVEDD $7.6 \mathrm{~cm}$, EF 25\%). Further regular outpatient followup has been arranged.

\section{Discussion}

Patients with impaired left ventricle function require a particular surgical strategy. Obviously, it is crucial to perform a routine procedure such as coronary grafting or valve surgery with meticulous surgical technique and good timing. Therefore, these patients should be operated on by senior surgeons. However, even in experienced hands, such cases may prove quite tricky. Sometimes, even perfect coronary anastomoses and the shortest ischemic time cannot prevent failed weaning from cardiopulmonary bypass. The possibility of perioperative mechanical support, exceeding the intra-aortic balloon pump, is quite tempting. One option is extracorporeal membrane oxygenation (ECMO), which can support the circulation for up to a few weeks. This requires, however, both arterial and venous cannulation, an aggressive anticoagulation regime and spe-

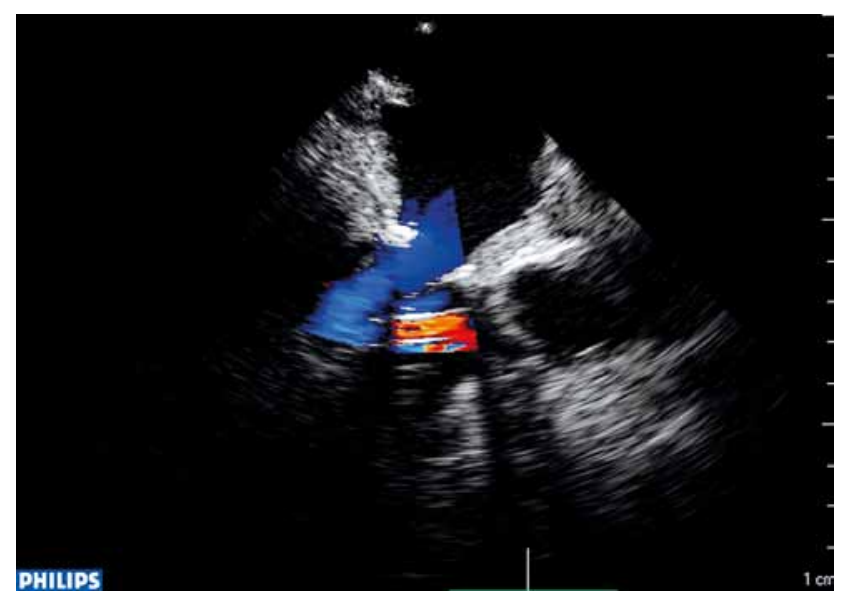

Fig. 4. Doppler scan showing the flow from the left atrium to the left ventricle (blue) and within the device from the left ventricle to the aorta (red)

cially trained perfusionists and nursing staff. Extracorporeal membrane oxygenation is also associated with a long list of potential complications including infection, bleeding, thromboembolic events, hemolysis and finally multiorgan failure (MOF). Left ventricle distension due to the lack of venting still remains an unsolved problem. The complex logistics and high cost of ECMO should not be ignored either. There is no doubt that ECMO is a well-established and recognized life-saving procedure; however, the question may be raised whether some patients could benefit from an easier technology used in a planned manner. This space could be filled by microaxial, rotating pumps. At the moment, there is quite a wide range of indications for their use [5], two in cardiology: as a rescue treatment in cardiogenic shock caused mainly by acute coronary syndrome [6] and, electively, as a support in high-risk percutaneous interventions including PCl and VT ablation $[7,8]$. Because of endovascular insertion and therefore limited device size (12 Fr) the generated flow cannot be higher than $2.5 \mathrm{l} / \mathrm{min}$, which usually is enough in the above situations. The other indications appear in cardiac surgery. Impella pumps may be applied in post-cardiotomy shock when an intra-aortic balloon is not enough to succeed in weaning from cardiopulmonary bypass [9]. Cardiac surgeons may also use them more electively as a perioperative support in patients with significantly impaired left ventricular function. That was our case. The surgical insertion can be performed either peripherally (Impella 5.0) or directly through the ascending aorta (Impella LD). In peripheral access the femoral or axillary artery is exposed, then the device is inserted using a tubing graft and forwarded to the left ventricle under fluoroscopic guidance. The hybrid theatre setting is required, but on the other hand it is possible to perform less invasive, thoracoscopic surgery. In direct access, after sternotomy, the implantation is quite easy under TEE guidance. The disadvantage is that resternotomy is required for explantation. Whatever the access, the surgical technique allows one to insert a bigger device ( $21 \mathrm{Fr}$ ), which is able to generate flow up to $5 \mathrm{l} / \mathrm{min}(!)$. That means that after the 
procedure, which is slightly more complex than insertion of an IABP, and having a device which is almost as easy to operate as an IABP, we achieve an effect that is very close to the benefit of left ventricular assist device (LVAD). The aforementioned problem of left ventricle venting is solved by definition, with Impella being an intraventricular device. There are reports about Impella applied simultaneously with ECMO to avoid left ventricle distension [10]. The only limitation is time. It should not stay in for longer than 5 days, which is more than enough to rethink and rearrange a new strategy. The Impella pump can be successfully used as a bridge to transplantation. One can easily imagine it as the first stage in the "bridge cascade" (Impella, ECMO, LVAD, recovery or transplant). When it is applied electively, as in our case, the chances are very high that only the first stage will be necessary. This being the case, the Impella pump can be deservedly regarded as a "short bridge to recovery".

\section{Disclosure}

Authors report no conflict of interest.

\section{References}

1. Toyoda Y, Guy TS, Kashem A. Present status and future perspectives of heart transplantation. Circ J 2013; 77: 1097-1110.

2. Garbade J, Barten MJ, Bittner HB, Mohr FW. Heart transplantation and left ventricular assist device therapy: two comparable options in end-stage heart failure? Clin Cardiol 2013; 36: 378-382.
3. Seyfarth M, Sibbing D, Bauer I, Fröhlich G, Bott-Flügel L, Byrne R, Dirschinger J, Kastrati A, Schömig A. A randomized clinical trial to evaluate the safety and efficacy of a percutaneous left ventricular assist device versus intra-aortic balloon pumping for treatment of cardiogenic shock caused by myocardial infarction. J Am Coll Cardiol 2008; 52: 1584-1588.

4. Cheng JM, den Uil CA, Hoeks SE, van der Ent M, Jewbali LS, van Domburg RT, Serruys PW. Percutaneous left ventricular assist devices vs. intra-aortic balloon pump counterpulsation for treatment of cardiogenic shock: a metaanalysis of controlled trials. Eur Heart J 2009; 30: 2102-2108.

5. Higgins J, Lamarche Y, Kaan A, Stevens LM, Cheung A. Microaxial devices for ventricular failure: a multicentre, population-based experience. Can J Cardiol 2011; 27: 725-730.

6. Lauten A, Engström AE, Jung C, Empen K, Erne P, Cook S, Windecker S, Bergmann MW, Klingenberg R, Lüscher TF, Haude M, Rulands D, Butter C, Ullman B, Hellgren L, Modena MG, Pedrazzini G, Henriques JP, Figulla HR, Ferrari M. Percutaneous left-ventricular support with the Impella-2.5-assist device in acute cardiogenic shock: results of the Impella-EUROSHOCK-registry. Circ Heart Fail 2013; 6: 23-30.

7. Sjauw KD, Konorza T, Erbel R, Danna PL, Viecca M, Minden HH, Butter C, Engstrøm T, Hassager C, Machado FP, Pedrazzini G, Wagner DR, Schamberger R, Kerber S, Mathey DG, Schofer J, Engström AE, Henriques JP. Supported high -risk percutaneous coronary intervention with the Impella 2.5 device the Europella registry. J Am Coll Cardiol 2009; 54: 2430-2434.

8. Bunch TJ, Darby A, May HT, Ragosta M, Lim DS, Taylor AM, DiMarco JP, Ailawadi G, Revenaugh JR, Weiss JP, Mahapatra S. Efficacy and safety of ventricular tachycardia ablation with mechanical circulatory support compared with substrate-based ablation techniques. Europace 2012; 14: 709-714.

9. Griffith BP, Anderson MB, Samuels LE, Pae WE Jr, Naka Y, Frazier OH. The RECOVER I: a multicenter prospective study of Impella 5.0/LD for postcardiotomy circulatory support. J Thorac Cardiovasc Surg 2013; 145: 548-554.

10. Koeckert MS, Jorde UP, Naka Y, Moses JW, Takayama H. Impella LP 2.5 for left ventricular unloading during venoarterial extracorporeal membrane oxygenation support. J Card Surg 2011; 26: 666-668. 